\title{
Seeing the invisible: Chriolepis lepidota (Gobiidae), literally as never seen before
}

J. Tavera* (1) and S. Rojas-Vélez

\begin{abstract}
Background: For the first time, almost half a century after its discovery and description, the poorly known endemic gobiid fish Chriolepis lepidota was seen alive at Malpelo Island.

Methods: During a 12-day expedition on March 2017, 18 specimens of this species were observed and photographed at different depths by means of SCUBA diving.

Results: Species maximum size and habitat preference are herein documented.

Conclusions: This sighting represents the first record of the species in the wild. Also, this report increases our knowledge on the ecology and biology of an unknown species.
\end{abstract}

Keywords: Malpelo Island, Endemic, Pretty goby, Fish

\section{Background}

The family Gobiidae includes about 210 genera and at least 1950 species, and is considered one of the most diverse groups among bony fishes (Nelson, 2006). Small size coupled with ecological and physiological flexibility has allowed members of this family to live in many different and sometimes harsh habitats (Thomson et al., 2000). Despite tropical habitats are rich in gobiids, they are often inconspicuous because of their tiny size and ecology; generally, gobies are cryptic species occupying crevices or interstices in the sand, reef or rocky substrates (Thacker, 2011). Even though, gobiids are an important component of the biodiversity in almost every environment, they are often poorly known and frequently misidentified. Amongst gobies the New World genus Chriolepis Gilbert 1892 are small, secretive, fishes with cryptobenthic lifestyle. They are sedentary species found in primarily insular and spatially restricted areas of reef-rock and rubble habitats in moderatelydeep to deep shelf waters, typically known from only a few specimens (Findley, Unpub. PhD Diss), (Hastings \& Findley, 2013; Hastings \& Findley, 2015). Recent molecular studies (Tornabene et al., 2016) recognized the non-monophyly of Chriolepis, recovering the

\footnotetext{
* Correspondence: jose.tavera@correounivalle.edu.co Laboratorio de Ictiología, Grupo de Investigación SEyBA, Departamento de Biología, Universidad del Valle, Cali, Colombia
}

Atlantic species Pycnomma roosevelti, and the Pacific Pycnomma semisquamatum (now Chriolepis roosevelti and C. semisquamata, respectively) nested within this genus. Chriolepis has divided pelvic fins, although the inner bases of the fins are closely approximated; typically, species have seven spines in the first dorsal fin (Findley, Unpub.PhD Diss). As currently defined, Chriolepis differs from other genera of seven-spined gobies in lacking head pores in all species but C. roosevelti (Ginsburg, 1939) and C. semisquamata (Rutter, 1904) and by having at least some pelvic-fin rays branched (Hastings \& Findley, 2015; Tornabene et al., 2016). Most species can be distinguished by extent of squamation or a combination of this character and color pattern. The inactive behavior of these secretive fishes, combined with small body size related to tightcrevice and rock-interspace inhabitation, has favored morphological adaptation and geographical isolation in these fishes (Findley, Unpub. PhD Diss). Eight species of Chriolepis occurs in the tropical eastern Pacific, three of which are endemics of oceanic islands with two of them only known from one or two specimens (e.g. pretty goby Chriolepis lepidota Findley 1975, Malpelo Island; and mystery goby Chriolepis tagus Ginsburg 1953, Galapagos Islands). This work presents for the first time, after its discovery, habitat data and photos in situ of the poorly known Malpelo endemic C. lepidota. 


\section{Methods}

Located on the Malpelo Ridge, a volcanic submarine crest that extends northeast-southwest, Malpelo $\left(4^{\circ} 0^{\prime} 07^{\prime \prime} \mathrm{N} ; 81^{\circ}\right.$ $36^{\prime} 27^{\prime \prime} \mathrm{W}$ ) is a small Colombian oceanic island in the East Pacific Ocean, separated from mainland by approximately $500 \mathrm{~km}$ and depths greater than $3300 \mathrm{~m}$ (Graham, 1975). The island is part of a Colombian National Natural Parks system and actually is considered as a wildlife sanctuary, declared by UNESCO as a natural World Heritage Site. The present island is the remnant of a much larger structure, once eight to ten times bigger than its present size (Stead, 1975). Cocos, Malpelo and Carnegie Ridges are interpreted to be traces that began to form when the Galápagos hotspot initiated at 20-22 Ma (Hey, 1977; Lonsdale et al., 1978). The Malpelo Ridge was separated from the Carnegie Ridge in the Miocene by now-extinct seafloor spreading (Lonsdale et al., 1978). Volcanic rocks from Malpelo Island yielded ages around $17 \sim 15 \mathrm{Ma}$ (Hoernle et al., 2002).

Malpelo is one of several oceanic volcanic islands in the tropical eastern Pacific that have never been connected, even by shallow water, with any other islands or the mainland (Graham, 1975). Weather has eroded the island forming steep cliffs and sea caves along its sides (Stead, 1975). The site in which C. lepidota was observed is known as "El Arrecife" (40'15.81"N; 81 36'15.80"W, Fig. 1). This location has Malpelo's largest coral formation, located between $4 \mathrm{~m}$ and $30 \mathrm{~m}$ depth (Chasqui et al., 2007), and a flat area with cobbles and rubble interspersed with large-grained sand consisting of eroded coral and shells. The flat area (5-10 m depth) extends to the east about $150 \mathrm{~m}$ and sinks in a steep slope down to $30 \mathrm{~m}$.

A total of 40 dives and 60 belt transects $(20 \times 2 \mathrm{~m})$ were made along different sites of the island, assessing

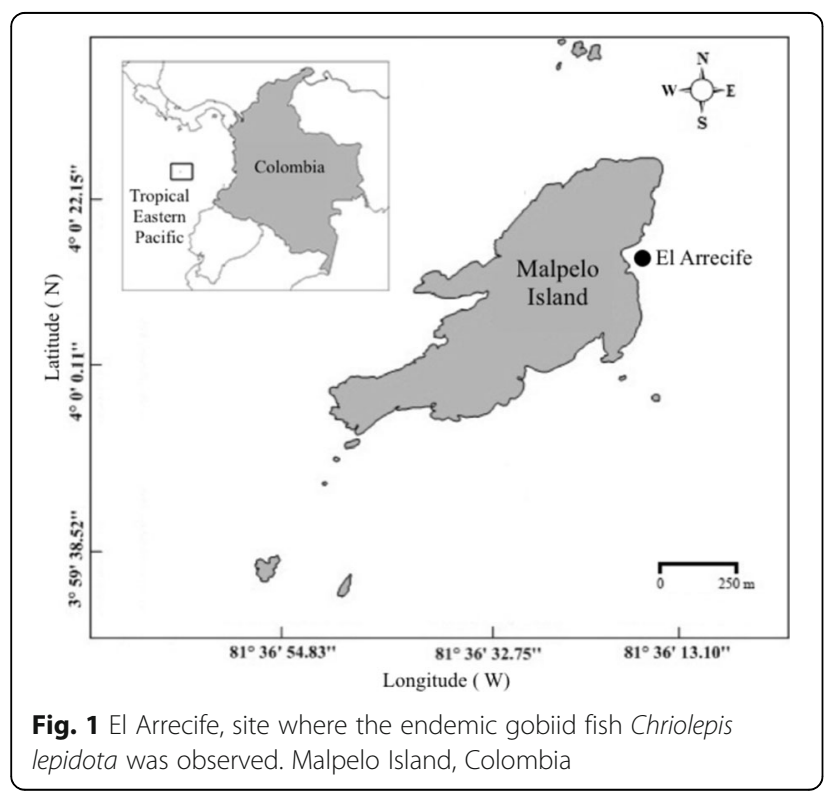

Malpelo's endemic fishes. Transects were performed at different depths ranks, along which fish were counted. According to depth of detection, two arbitrarily categories were designated: shallow for individuals seen above $10 \mathrm{~m}$ and deep for those observed below $10 \mathrm{~m}$. Additionally, the diameter of individual grains of sediment, where the fish were hidden, was considered and its classification follows Wentworth scale (Wentworth, 1922). Finally, fish size was estimated by means of a PVC tube labeled each $\mathrm{cm}$.

A combination of remoteness plus enough evolutionary time has driven speciation biogeographic isolation at Malpelo Island, as a consequence five endemic fish species, one of them C. lepidota, exist on the island (Chasqui et al., 2011; Robertson \& Allen, 2015). This species had only been seen dead, after two specimens were collected using rotenone-based ichthyocide and SCUBA diving during the 1972 Smithsonian InstitutionU.S. Navy Expedition to Malpelo Island. Findley (1975) (Findley, 1975) described the species, and the holotype and paratype (the only known specimens, up to this day) were deposited in the National Museum of Natural History (USNM), Smithsonian Institution, Washington, D. C., under catalog numbers, USNM 211456 and 211,457 . Until this record, a very good sketch of the species illustrated by Jeanean Thomson was the only image available of this fish (Fig. 2) (Findley, 1975). Chriolepis lepidota can be easily distinguished from the additional three species of gobies found at Malpelo Island (Bollmania spA, Coryphopterus urospilus and Lythrypnus dalli) by having 7 spines on dorsal fin; pelvic fins completely separated; and by its marbled coloration, containing small black and white spots scattered over head and body; 2 black spots on pectoral base; 5 brown bands on body made-up by 2 dark areas separated by a whitish spotted line; yellow-whitish interspaces between bands with a brownish narrow vertical mid-line; a dorsal white thin line over head just behind the eyes; and a dark bar at the base of the caudal fin across the caudal peduncle. Dorsal (VII,11), anal (10 total elements) and pectoral (20) fin counts (made on photographs), as well as color pattern corresponds in many ways to original drawing and description of the species (see Fig. 2 and Fig. 3) (Findley, 1975).

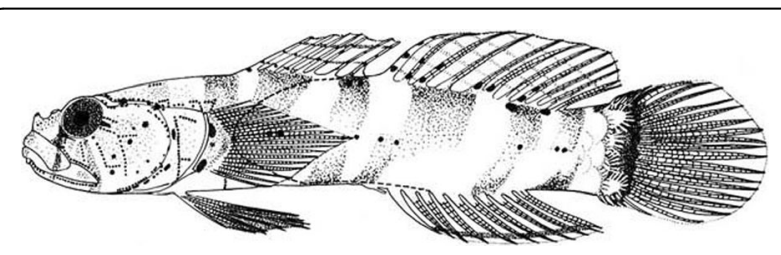

Fig. 2 Chriolepis lepidotus, holotype, USNM 211456, male, 30.0 mm SL. Drawing by Jeanean Thomson. Reproduced with permission of Lloyd Findley 


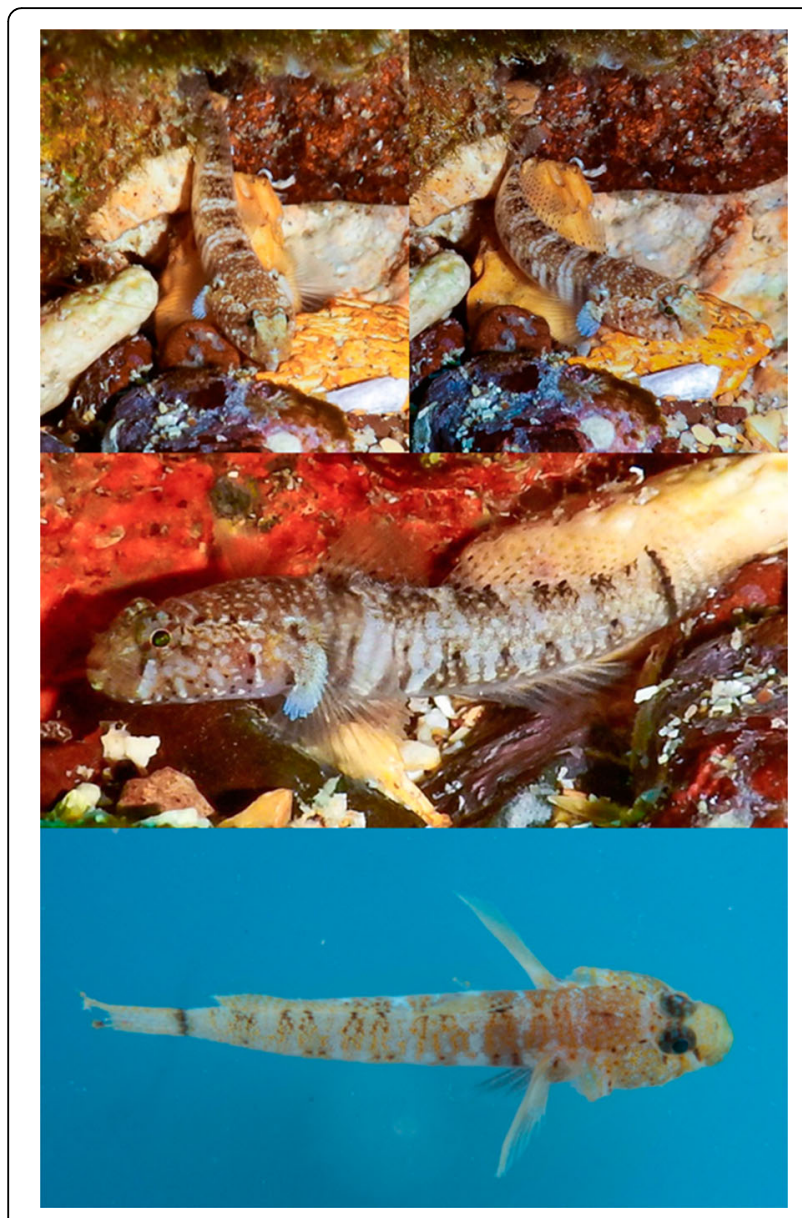

Fig. 3 Photographs of Chriolepis lepidota at Malpelo Island, Colombia. Pictures credit belongs to Stephania Rojas

\section{Results}

Almost half a century passed before $C$. lepidota, a fish that had never been seen alive, could be detected. During a 12day expedition made from the $5^{\text {th }}$ to the $16^{\text {th }}$ of March 2017, several specimens of the species were photographed (Fig. 3). Coincidentally the only two specimens known of this species were also collected in March (2nd and 3rd) back in 1972 . The banded color pattern shown by $C$. lepidota, certainly related to its cryptic mode of life, kept this species out of sight for 45 years. C. lepidota was discovered on the east side of the island and its identity was confirmed using (Robertson \& Allen, 2015; Findley, 1975) and (Findley, Unpub. PhD Diss). The small marbled looking fish was observed, at depths between $8 \mathrm{~m}$ to $18 \mathrm{~m}$, over rocky bottom with some calcareous sand and very sparse algal growth. Ten small $(2-4 \mathrm{~cm})$ specimens were detected, on the flat portion of El Arrecife, posed over cobbles where they seek refuge underneath few seconds after being recognized. Eight bigger specimens $(4-7 \mathrm{~cm})$, were found deeper over the slope hidden in crevice-like interspaces under or at the bases of boulder size rocks.
The habitat in which C. lepidota was found corresponds accurately with previous descriptions of preferred habitats in which most eastern Pacific Chriolepis have been collected (Findley, Unpub. PhD Diss). Our observations extend species maximum size to approx. $6 \mathrm{~cm}$.

\section{Discussion}

C. lepidota distribution suggests that habitat segregation might be related to size, with smaller individuals $(n=10)$ living on flat shallower bottoms underneath cobbles, and bigger ones $(n=8)$ found over the slope hidden in the interspaces under boulders and rocks crevices sheltered at the interface between sand and rock. Possibly, three major environmental gradients, acting together or independently, influence species segregation: substrate inclination, depth and grain size (Fig. 4). This preliminary result prompts a testable hypothesis for future ecological studies.

According to the IUCN red list of threatened species C. lepidota is considered as Vulnerable (Findley \& Van Tassell, 2010), being the increased duration and frequency of ENSO events the mayor threats identified, given the restricted range of this species. Despite being an endemic to Malpelo Island, regional assessment includes it under the category Data Deficient given the

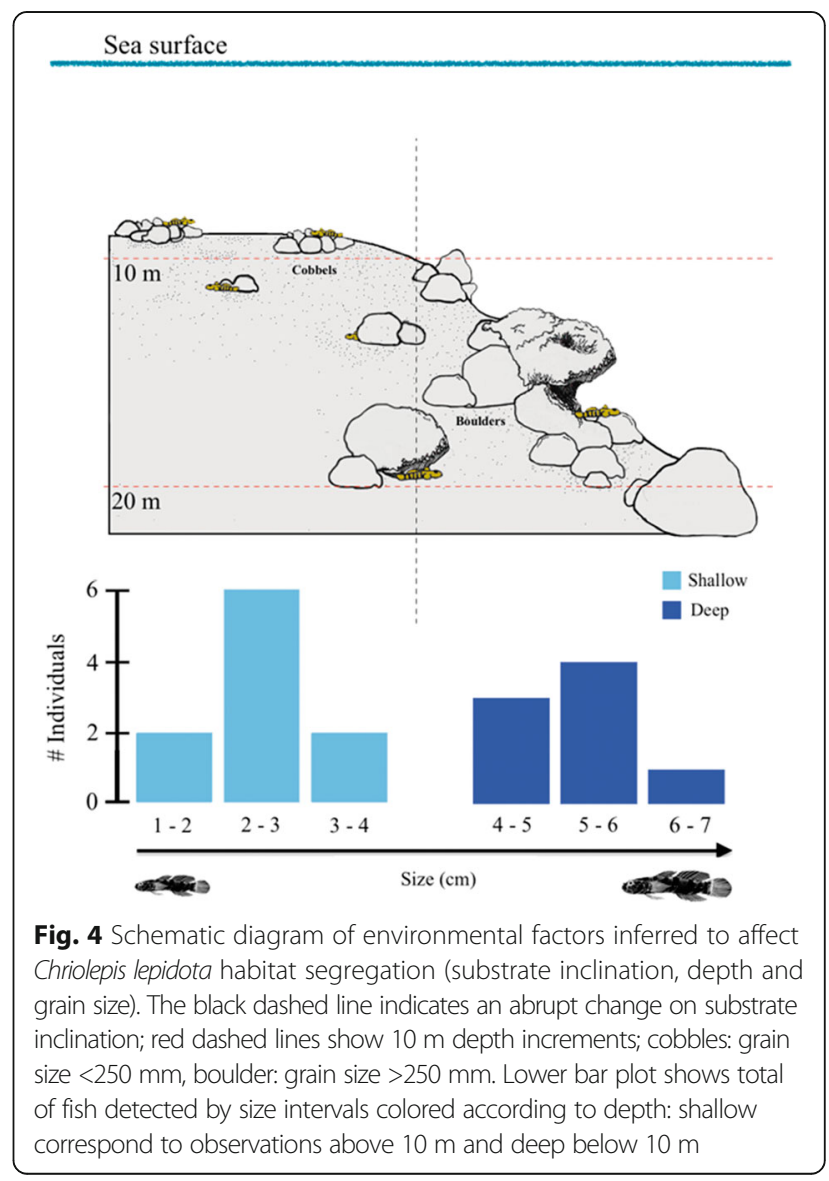


lack of information available for the species (Zapata \& Chasqui, 2017). This paper constitutes the first data published for this species since its discovery.

Finally, there is much more to investigate about this endemic species. Quoting J. L. B. Smith (1958) in (Findley, Unpub. PhD Diss): "The gobioid fishes are one of the major trials of ichthyologists... Being of little or no economic significance, although normally abundant, especially in tropical areas, these fishes are virtually unknown to any but the expert seeking them".

\section{Conclusions}

Up to this date, reports regarding Chriolepis lepidota were lacking and the existence of the species was even questioned. This report represents the first record of $C$. lepidota after its description (1975) and increases our biological and ecological knowledge on this cryptic species. It also highlights the need for a comprehensive assessment of Pacific Colombian fish diversity, which have been overseen for decades.

\section{Acknowledgments}

We would like to thank Fernando Zapata and his research group "Ecología de Arrecifes Coralinos", all personnel from SFF Malpelo, people from Fundación Malpelo y otros Ecosistemas Marinos and to Maria Patricia vessel crew. Also, to Arturo Acero and two anonymous reviewers for reading and commenting on an early version of this manuscript. Finally, Lloyd Findley which kindly allow us to use C. lepidota original drawing.

\section{Funding}

Not applicable.

\section{Availability of data and materials}

Not applicable.

\section{Authors' contributions}

JT sight and identified the fish, collected data and drafted the manuscript; SRV collected data photographed C. lepidota and reviewed the manuscript. Both authors read and approved the final manuscript.

\section{Ethics approval and consent to participate}

Not applicable.

\section{Consent for publication}

Not applicable.

\section{Competing interests}

The authors declare that they have no competing interests.

\section{Publisher's Note}

Springer Nature remains neutral with regard to jurisdictional claims in published maps and institutional affiliations.

Received: 15 June 2017 Accepted: 14 August 2017

Published online: 23 August 2017

\section{References}

Chasqui L, Gil-Agudelo DL, Nieto R. Endemic shallow reef fishes from Malpelo Island: abundance and distribution. Bol de Investig Marinas y Costeras INVEMAR. 2011;40:107-16.

Chasqui L, Zapata FA. Tamaño y composición de dos formaciones coralinas del Santuario de Fauna y Flora Malpelo, Pacífico colombiano. In: INVEMAR, editor. Informe del estado de los ambientes marinos y costeros en Colombia: Año 2006. Santa Marta: INVEMAR; 2007. p. 96-101.
Findley L, Van Tassell J. Chriolepis lepidota. In: The IUCN Red List of Threatened Species 2010. 2010. https://doi.org/10.2305/IUCN.UK.2010-3.RLTS. T183325A8093991.en. Accessed 21 Apr 2017.

Findley LT. A new species of goby from Malpelo Island (Teleostei: Gobiidae: Chriolepis). Smithson Contrib Zool. 1975;176:94-8.

Graham JB. The biological investigation of Malpelo Island, Colombia. Washington: Smithsonian Institution Press; 1975.

Hastings PA, Findley LT. Chriolepis bilix, a new species of goby (Teleostei: Gobiidae) from deep waters of the western Atlantic. Zootaxa. 2013; doi:10. 11646/zootaxa.3745.5.8

Hastings PA, Findley LT. Chriolepis prolata, a new species of Atlantic goby (Teleostei: Gobiidae) from the north American continental shelf. Zootaxa. 2015: doi:10.11646/zootaxa.3904.4.8.

Hey R. Tectonic evolution of the Cocos-Nazca spreading center. Geol Soc Am Bull. 1977; doi:https://doi.org/10.1130/0016-7606(1977)88<i:TEOTCS>2.0.CO;2.

Hoernle K, van den Bogaard P, Werner R, Lissinna B, Hauff F, Alvarado G, GarbeSchönberg D. Missing history (16-71 ma) of the Galápagos hotspot: implications for the tectonic and biological evolution of the Americas. Geology. 2002; doi:https://doi.org/10.1130/0091-7613(2002)030<0795: MHMOTG>2.0.CO;2.

Lonsdale P, Klitgord KD, et al. Geol Soc Am Bull. 1978; doi:https://doi.org/10.1130/ 0016-7606(1978)89<981:SATHOT>2.0.CO;2.

Nelson J. Fishes of the world. 4th ed. Hoboken: John Wiley \& Sons; 2006.

Robertson DR, Allen GR. Shorefishes of the Tropical Eastern Pacific: online information system. Version 2.0 Smithsonian Tropical Research Institute, Balboa, Panamá. 2015. http://biogeodb.stri.si.edu/sttep/es/pages. Accessed 21 Apr 2017.

Stead JA. Field observations on the geology of Malpelo Island. Smithson Contrib Zoolo. 1975;176:17-20.

Thacker CE. Systematics of Gobiidae. In: Patzner RA, Van Tassell JL, Kovacic M Kapoor BG, editors. Biology of gobies. Boca Raton: Science Publishers; 2011. p. 129-36.

Thomson DA, Findley LT, Kerstitch AN. Reef fishes of the sea of Cortez. The rockyshore fishes of the Gulf of California. Revised ed. Austin: The University of Texas Press; 2000

Tornabene L, Van Tassell JL, Gilmore RG, Robertson DR, Young F, Baldwin CC. Molecular phylogeny, analysis of character evolution, and submersible collections enable a new classification for a diverse group of gobies (Teleostei: Gobiidae: Nes subgroup), including nine new species and four new genera. Zool J Linnean Soc. 2016; doi:https://doi.org/10.1111/zoj.12394.

Wentworth CK. A scale of grade and class terms for Clastic sediments. J Geology. 1922; doi:https://doi.org/10.1086/622910.

Zapata FA, Chasqui L. Chriolepis lepidota. In: Chasqui L, Polanco A, Acero A, Mejía-Falla PA, Navia A, Zapata LA, Caldas JP, editors. Libro rojo de peces marinos de Colombia. Santa Marta: Instituto de Investigaciones Marinas y Costeras Invemar; 2017. p. 413-5.
Submit your next manuscript to BioMed Central and we will help you at every step:

- We accept pre-submission inquiries

- Our selector tool helps you to find the most relevant journal

- We provide round the clock customer support

- Convenient online submission

- Thorough peer review

- Inclusion in PubMed and all major indexing services

- Maximum visibility for your research

Submit your manuscript at www.biomedcentral.com/submit
Ciomed Central 